\title{
Evaluation of Morphological and Molecular Diversity among the Genotypes of Eleusine africana, Cultivated and Weedy Types of Finger Millet (Eleusine coracana L. Gaertn.)
}

\author{
Chitra Joshi", Sunil Subramanya and R.L. Ravikumar \\ Department of Plant Biotechnology, University of Agricultural Sciences, GKVK, \\ Bangalore-560 065, India \\ *Corresponding author
}

\begin{abstract}
A B S T R A C T
Keywords

Finger millet, $E$. africana, SSR markers, Multivariate analysis, Genetic diversity

\section{Article Info}

Accepted:

16 January 2018

Available Online:

10 February 2018

The present study was carried out to understand the extent of morphological and molecular variability between cultivated finger millet genotypes of Indian and African origin and weedy E. coracana and E. africana genotypes. A total of 28 genotypes representing cultivated varieties (E. coracana) from India and Africa, wild species (E. africana) and weedy types of $E$. coracana were grown in field and scored for 23 morphological traits. The African cultivated types were distinct from Indian types for many morphological traits. The E. africana and weedy E. indica genotypes formed a separate cluster based on qualitative traits as well as molecular markers. The clustering and multivariate analysis conducted with morphological as well as molecular data, could divide the cultivated genotypes separately from wild and weedy types. The weedy type EC516243 S1 having relatively bolder seeds and superior productivity related traits were identified as suitable breeding materials for hybridisation with cultivated types.

\section{Introduction}

Finger millet (Eleusine coracana L. Gaertn.) is a highly self-pollinated, allotetraploid $(2 \mathrm{n}=$ $4 \mathrm{x}=36$ ) annual crop, member of the family Poaceae, sub-family Chloridiodeae and tribe Chlorideae and native to Uganda and Ethiopian regions of Africa (Harlan, 1971; deWet, 1995). In world, finger millet ranks fourth in importance among millets after sorghum, pearl millet and foxtail millet with major producers being Uganda, India, Nepal and China having a yield potential of more than 10 tonnes per hectares under irrigated conditions (Goron and Raizada, 2015). In

India, finger millet commonly known as ragi is cultivated in an area of 1190 thousand hectares with the average productivity of 1631 $\mathrm{kg}$ per hectares (AICRPSM, 2016). The production area of finger millet in India stands sixth after wheat, rice, maize, sorghum and bajra and Karnataka is the leading producer accounting to 58 per cent of its global production. Recently the area under finger millet is drastically reduced in all the major growing states of India, particularly Karnataka (Michaelraj and Shanmugam, 2013). However with global climate change and hidden hunger of the growing population, finger millet has a significant role to play in the future.
\end{abstract}


Therefore, there is a need to enhance the variability in the cultivated tetraploids with increased adaptability to climate change. In this direction, the tetraploid wild and weedy Eleusine species have a significant allelic contribution for adaptive agriculture.

The morphological and molecular diversity present among the different species of Eleusine is immense. Diffusion of the finger millet crop from its primary centre of diversity, situated in the East African regions where primitive cultivars and weedy forms exist (Chennaveeraiah and Hiremath, 1974) to other areas has led to the accumulation of diversity in secondary centre of diversity which is considered to be India (Dida et al., 2008). However, the assessment of genomic relationships between cultivated $E$. coracanca and its wild tetraploid species has been limited. Assessment of the genetic diversity and relationships using microsatellites or SSR markers provide wide and unique opportunities to quickly and accurately access the allelic diversity variability between cultivated Eleusine species and other tetraploid types of Eleusine for their utilization in crop improvement programmes of the finger millet.

\section{Materials and Methods}

\section{Plant material}

The experimental plant material for the present investigation consisted of eleven cultivated genotypes of Eleusine coracana from India, six cultivated genotypes from Africa, nine Eleusine africana accessions and two weedy E. coracana from India (Table 1). The seeds of these genotypes were obtained from All India Coordinated Research Project on Small Millets (University of Agricultural Sciences GKVK), Bangalore. All the genotypes were germinated in the laboratory by providing seed treatment $(0.3 \%$ Hydrogen peroxide; Katzman et al., 2001) and transplanted to field during kharif 2016 at UAS GKVK, Bangalore. Each genotype was transplanted in a single row of 2.5 meters length with $30 \times 10 \mathrm{~cm}$ spacing. The crop was grown under irrigation with recommended agronomic practices.

\section{Morphological characterization}

For each genotypes five plants were randomly selected for recording observations on qualitative traits like growth habit, plant pigmentation at leaf juncture, leaf sheath pubescence, glume color, culm branching, ear shape, finger branching, position of finger branching, multiple whorl, seed shattering, seed covering by glumes, seed color, seed shape, seed surface as well as quantitative traits, including days to $50 \%$ flowering, flag leaf blade length $(\mathrm{cm})$, flag leaf blade width $(\mathrm{cm})$, ear head length $(\mathrm{cm})$, finger length $(\mathrm{cm})$, finger width $(\mathrm{cm})$, finger number, number of productive tillers /plant and plant height at maturity $(\mathrm{cm})$ were recorded at different developmental stages as per the finger millet descriptor (IBPGR, 1985). The mean values were used for further analysis.

\section{Isolation of genomic DNA}

Fourteen genotypes (five cultivated genotypes of India, four cultivated genotypes of Africa, three E. africana accessions and two weedy types of E. coracana) were selected for molecular analysis. The genomic DNA was extracted from young leaves of single representative plant in each genotype following CTAB extraction method (mini preparation) as described by Doyle and Doyle (1987).

The DNA was diluted to $50 \mathrm{ng} / \mu \mathrm{l}$ concentration for SSR genotyping after purity assessment in Nanodrop spectrophotometer (ThermoScientific, USA). 


\section{Microsatellite markers and PCR analysis}

A set of 21 finger millet EST- SSR primer pairs (Table 2) were used for PCR amplification and molecular diversity analysis. The PCR amplification reactions were carried out in Mastercycler nexus gradient (Eppendorf, Germany) with $10 \mu \mathrm{l}$ reaction mixture containing $50 \mathrm{ng}$ of genomic DNA, $2 \mathrm{mM}$ dNTPs, $10 \mathrm{pMol}$ each of forward and reverse primers, $1 \mathrm{U} / \mu 1$ Taq DNA Polymerase and 1X PCR buffer. The PCR was performed with an initial denaturation at $95^{\circ} \mathrm{C}$ for $5 \mathrm{~min}$ followed by 38 cycles of $30 \mathrm{sec}$ denaturation at $94^{\circ} \mathrm{C}, 45 \mathrm{sec}$ annealing at different temperatures based on primer pairs and $1 \mathrm{~min}$ extension at $72^{\circ} \mathrm{C}$ with a final extension at $72^{\circ} \mathrm{C}$ for $8 \mathrm{~min}$. The PCR products were separated and visualized on a $3.5 \%$ agarose gel and the fragment sizes were estimated by comparison with 100 base pair (bp) DNA ladder.

\section{Statistical analysis}

The hierarchical cluster of the genotypes was obtained separately for total morphological traits and qualitative traits by UPGMA (Unweighted Pair-Group Method using Arithmetic Average) analysis with Continuous (Usual Euclidean) dissimilarity index using DARwin 6 (Perrier $\mathrm{X}$ and Jacquemoud-Collet J. P. 2006) software. The qualitative characters that depict an array of characters were converted into binary characters based on various pretext in each trait. The quantitative data gathered on different traits were standardized to zero mean and a unit variance.

The amplicons were scored according to their product size for each genotype and primer combination. The allelic data were subjected to estimation of genetic distances among the genotypes. Each amplified band was treated as an independent locus and were scored based on present (1) or absent (0) system. The Sequential Agglomerative Hierarchical Non overlapping (SAHN) clustering on squared Elucidean distance matrix and similarity matrix utilizing UPGMA method based on Jaccard similarity coefficient was employed for cluster analysis and estimation of genetic similarity respectively using the software package NTSYSpc 2.02i (Rohlf, 1998).

The estimation of the major allele frequency, allele number, gene diversity index and polymorphic information content (PIC) value was done using Power Marker v3.0 software (Liu and Muse, 2005). The principal component analysis (PCA) with data on nine quantitative morphological traits and principal coordinate analysis (PCoA) based on Jaccard similarity index with 21 EST-SSR marker scores were conducted separately using PAST v3.15 software (Hammer et al., 2001).

\section{Results and Discussion}

\section{Diversity analysis and grouping based on morphological data}

The cultivated genotypes from Africa had differentiating characters from Indian cultivated types in terms of having dark green glume colour, presence of finger branching in all fingers and higher mean for quantitative traits like flag leaf blade length, ear head length, finger numbers on main ear and plant height at maturity (Table 3). The morphological differences between Indian and African cultivated accessions with respect to inflorescence characters have also been reported by Naik et al., (1993), Upadhyaya et al., (2006) and Babu et al., (2014a). However, when compared among all four groups of genotypes, wild species (E. africana) and weedy types of $E$. coracana had higher mean for most of the quantitative traits. Therefore, the wild and weedy species can be exploited for improvement of quantitative traits in finger 
millet (Mariam et al., 1996). The EC516243 S1, a weedy type which had relatively bolder seeds, higher mean for finger length, ear head length, finger width and plant height was identified suitable for hybridization programmes with cultivated genotypes. Attempts are being made to cross EC 516243S1 to cultivated high yielding genotype (GPU 28) for introgression of the desirable traits.

The dendrogram based on UPGMA clustering constructed with 23 morphological parameters for 28 genotypes divided the genotypes into two major clusters (Fig. 1). The cluster I had 27 genotypes whereas the cluster II had only one accession, EC516243 S1 which was morphological distinct among all the genotypes. The first cluster was divided into several sub-clusters, however the grouping of genotypes didn't follow any specific pattern. To have a more credible picture of the morphological differences among the genotypes another dengrogram based on 14 qualitative traits was constructed which divided the genotypes into two major clusters (Fig. 2). The qualitative characters provide a means of characterizing and differentiating genotypes morphologically from one another. The cluster I had all the 17 cultivated genotypes (E. coracana) whereas all the 11 genotypes of wild species (E. africana) and weedy types were grouped in the cluster II. However, the clustering of cultivated genotypes was not based on geographical origins which is in accordance with the previous reports by Upadhyaya et al., (2006) and Kumar et al., (2010).

The principal component analysis (PCA) of 28 genotypes using nine quantitative traits revealed that the traits like ear head length, finger length, productive tillers / plant, plant height at maturity, finger width and flag leaf length contributed more to the diversity which is in agreement with the previous reports by
Reddy et al., (2009), Nethra et al., (2014), Ulaganathan and Nirmalakumari (2015) and Mahanthesha et al., (2017). The highest contribution to the first principal component which accounted for $38.33 \%$ to the total variation came from finger length (0.47) followed by ear head length (0.46) (Table 4). The traits like finger numbers/ear head, finger width, flag leaf length and flag leaf width showed negative contribution. Similarly, the plant height contributed highest (0.52) followed by flag leaf length (0.43), to the second principal component which accounted for $23.27 \%$ to the total variation (Table 4). The characters like days to $50 \%$ flowering, productive tillers/plant and finger width contributed negatively. All the cultivated genotypes except GE 12 concentrated separately from genotypes of E. africana and weedy types in quadrant 2 and 3 of scatter biplot (Fig.3). GE 12, an Indian cultivated genotype was found to be distant from the cluster of other cultivated genotypes due to its distinct ear head shape of open type, highest ear head length, finger length and plant height among cultivated genotypes.EC516243 S1 (weedy type) and GE 7130 (E. africana) were dispersed distantly in PC1 and PC2 respectively which is in concordant with the pattern found in clustering analysis (Fig. 1\& 2).

\section{Diversity analysis and grouping based on molecular marker data}

The present study showed relatively lower polymorphism (42.86\%) with only nine out of 21 SSR markers were polymorphic among cultivated and other weedy genotypes. Babu et al., (2014a, b) also reported low polymorphism in their study involving 190 cultivated genotypes and 95 SSR markers. The mean major allele frequency was higher for cultivated genotypes (0.94) as compared to the wild species (E. africana) and weedy types (0.89). 
Table.1 Details of the plant material used in the present study

\begin{tabular}{|c|c|c|c|}
\hline SI. No. & Genotype & Country & Species \\
\hline 1. & GE 6 & \multirow{11}{*}{ India } & \multirow[t]{17}{*}{ E. coracana } \\
\hline 2. & GE 12 & & \\
\hline 3. & GE 13 & & \\
\hline 4. & GE 14 & & \\
\hline 5. & GE 1598 & & \\
\hline 6. & GE 1599 & & \\
\hline 7. & GE 1600 & & \\
\hline 8. & GE 1606 & & \\
\hline 9. & GE 1607 & & \\
\hline 10. & GE 2403 & & \\
\hline 11. & PR 202 & & \\
\hline 12. & GE 1595 & Africa & \\
\hline 13. & GE 1612 & \multirow{5}{*}{ Uganda } & \\
\hline 14. & GE 1613 & & \\
\hline 15. & GE 1615 & & \\
\hline 16. & GE 1616 & & \\
\hline 17. & GE 1618 & & \\
\hline 18. & GE 7123 & \multirow{9}{*}{ Not known } & \multirow[t]{9}{*}{ E. africana } \\
\hline 19. & GE 7124 & & \\
\hline 20. & GE 7125 & & \\
\hline 21. & GE 7126 & & \\
\hline 22. & GE 7127 & & \\
\hline 23. & GE 7128 & & \\
\hline 24. & GE 7129 & & \\
\hline 25. & GE 7130 & & \\
\hline 26. & GE 7131 & & \\
\hline 27. & EC516243 IPS-3 & \multirow[t]{2}{*}{ Not known } & \multirow{2}{*}{$\begin{array}{c}\text { Weedy type of } E \\
\text { coracana }\end{array}$} \\
\hline 28. & EC516243 S1 & & \\
\hline
\end{tabular}


Table.2 The sequence details of EST-SSR primers used for molecular diversity study and the number of alleles generated

\begin{tabular}{|c|c|c|c|}
\hline $\begin{array}{l}\text { SI. } \\
\text { No. }\end{array}$ & Primer & Sequence (5'-3') & $\begin{array}{l}\text { Number of } \\
\text { alleles }\end{array}$ \\
\hline \multirow[t]{2}{*}{1.} & \multirow{2}{*}{ FM 70} & F- GAGTCTATGATCCGCTCTTG & \multirow{2}{*}{1} \\
\hline & & R-CACGAATTAGACATGGGATT & \\
\hline \multirow[t]{2}{*}{2.} & \multirow[t]{2}{*}{ FM 77} & F- GGGAGGTCGACTAAGCTG & \multirow[t]{2}{*}{2} \\
\hline & & R- AACTTGTCCTGCATCATCTC & \\
\hline \multirow[t]{2}{*}{3.} & \multirow[t]{2}{*}{ UGEP 26} & F- ATGGGGTTAGGGTTCGAGTC & \multirow[t]{2}{*}{1} \\
\hline & & R- TGTCCCTCACTCGTCTCCTC & \\
\hline \multirow[t]{2}{*}{4.} & \multirow[t]{2}{*}{ UGEP 76} & F- GCACGTACGGATTCACATTG & \multirow[t]{2}{*}{2} \\
\hline & & R-GGTACGGAGACATCGACACC & \\
\hline \multirow[t]{2}{*}{5.} & \multirow[t]{2}{*}{ UGEP 21} & F- CAATTGATGTCATTGGGACAAC & \multirow[t]{2}{*}{2} \\
\hline & & R- GTATCCACCTGCATGCCAAC & \\
\hline \multirow[t]{2}{*}{6.} & \multirow{2}{*}{ UGEP 110} & F- AAATTCGCATCCTTGCTGAC & \multirow[t]{2}{*}{1} \\
\hline & & R-TGACAAGAGCACACCGACTC & \\
\hline \multirow[t]{2}{*}{7.} & \multirow[t]{2}{*}{ UGEP 77} & F- TTCGCGCGAAATATAGGC & \multirow[t]{2}{*}{2} \\
\hline & & R- CTCGTAAGCACCCACCTTTC & \\
\hline \multirow[t]{2}{*}{8.} & \multirow[t]{2}{*}{ FMBLESTSSR 20} & F- AGAGGAACCGCTCATTCAGATA & \multirow[t]{2}{*}{2} \\
\hline & & R-GGGGTAGAAAGTCTGGGAAATC & \\
\hline \multirow[t]{2}{*}{9.} & \multirow[t]{2}{*}{ FMBLESTSSR 13} & F- GCTAAAGACAAAGAGTGCCCAT & 2 \\
\hline & & R- AАATATCCСТCTGCCАСТТСCT & \\
\hline 10. & FMBLESTSSR 19 & F- CCAACTTCTGGTTTTAACGTCC & 1 \\
\hline & & R- GTGGTAACTTTTCTGGCACCTC & \\
\hline 11. & FMBLESTSSR 43 & F- GAGGCCCACACACTTCTTAGCGA & 1 \\
\hline & & R-GGAGTATGGGTAGTGGAACCAGTG & \\
\hline 12. & FMESTSSR 17 & F- CATCTCCАТCТCСАТСТCСА & 2 \\
\hline & & R- AAGGACGATCGCAACCAG & \\
\hline 13. & FMESTSSR 21 & F- CGCTAGTAGTACATCACAGCTA & 1 \\
\hline & & R-CTGATGGCGTATGGGAGTCT & \\
\hline 14. & FMESTSSR 16 & F-GAGGCATGCACGTACAACAC & 1 \\
\hline & & R- GGAGGGAGGGAATTCACAAT & \\
\hline 15. & FMESTSSR 29 & F- CCACCTGCТCCАТCTАCATCT & 2 \\
\hline & & R- AAGGACGATCGCAACCAG & \\
\hline 16. & FMBLESTSSR 3 & F-GGATGAAGTGAGATTCCCCATA & 2 \\
\hline & & R- CAAGCTCTTCTGTGTTGCACTC & \\
\hline 17. & FMBLESTSSR 36' & F- CTCGCAGTGACAGGGCTT & 1 \\
\hline & & R- GTGTTTGTGTTGTGTGCTGTGT & \\
\hline 18. & FMBLESTSSR 2 & F- TATGGGACATCTGCTCAAAGA & 1 \\
\hline & & R-AGAAGGCAGGTGAACGTAACTC & \\
\hline 19. & FMBLESTSSR 4 & F- TTGTCTGGGATGACTTGAACAG & 1 \\
\hline & & R- AGCTCGTGGTACTTATGGAAGG & \\
\hline 20. & FMBLESTSSR 29 & F- AGCTTTCGGAGGGAAGTTAGAC & 1 \\
\hline & & R-ACGGTTATGAGAAGTGGAAATG & \\
\hline 21. & FM SSR 01 & F-GCGAAAACACAATGCAAAAA & 1 \\
\hline & & R- GCGTTGGTTGGACCTGAC & \\
\hline
\end{tabular}


Table.3 The mean \pm SE values for 9 quantitative morphological traits among the genotypes

\begin{tabular}{|c|c|c|c|c|c|c|c|c|c|c|c|}
\hline $\begin{array}{l}\text { Sl. } \\
\text { No. }\end{array}$ & Genotypes & $\mathbf{N}$ & $\begin{array}{c}\text { Days to } \\
50 \% \\
\text { flowering }\end{array}$ & $\begin{array}{l}\text { Plant } \\
\text { Height } \\
\text { (cm) }\end{array}$ & $\begin{array}{c}\text { Productive } \\
\text { tillers } \\
\text { /plant }\end{array}$ & $\begin{array}{c}\text { Finger } \\
\text { number } \\
\text { on } \\
\text { main ear }\end{array}$ & $\begin{array}{c}\text { Finger } \\
\text { Width } \\
\text { (cm) }\end{array}$ & $\begin{array}{c}\text { Finger } \\
\text { length } \\
(\mathrm{cm})\end{array}$ & $\begin{array}{c}\text { Ear } \\
\text { head } \\
\text { length } \\
(\mathrm{cm})\end{array}$ & $\begin{array}{c}\text { Flag } \\
\text { leaf } \\
\text { length } \\
(\mathrm{cm})\end{array}$ & $\begin{array}{r}\text { Flag } \\
\text { leaf } \\
\text { width } \\
(\mathrm{cm})\end{array}$ \\
\hline 1 & $\begin{array}{l}\text { Cultivated } \\
\text { genotypes } \\
\text { from India }\end{array}$ & 11 & $\begin{array}{l}42.91 \\
\pm 1.80\end{array}$ & $\begin{array}{c}112.71 \pm 5 \\
.76\end{array}$ & $\begin{array}{c}6.20 \\
\pm 1.27\end{array}$ & $\begin{array}{c}8.33 \\
\pm 0.57\end{array}$ & $\begin{array}{c}1.10 \\
\pm 0.06\end{array}$ & $\begin{array}{c}7.10 \\
\pm 0.75\end{array}$ & $\begin{array}{c}8.11 \\
\pm 0.84\end{array}$ & $\begin{array}{l}44.52 \\
\pm 1.91\end{array}$ & $\begin{array}{c}1.21 \\
\pm 0.07\end{array}$ \\
\hline 2 & $\begin{array}{l}\text { Cultivated } \\
\text { genotypes } \\
\text { from Africa }\end{array}$ & 6 & $\begin{array}{l}40.67 \\
\pm 0.67\end{array}$ & $\begin{array}{c}128.10 \pm 4 \\
.58\end{array}$ & $\begin{array}{c}3.20 \\
\pm 0.23\end{array}$ & $\begin{array}{c}9.13 \\
\pm 0.79\end{array}$ & $\begin{array}{c}1.05 \\
\pm 0.03\end{array}$ & $\begin{array}{c}6.59 \\
\pm 0.60\end{array}$ & $\begin{array}{c}8.26 \\
\pm 0.62\end{array}$ & $\begin{array}{l}53.14 \\
\pm 2.59\end{array}$ & $\begin{array}{c}1.30 \\
\pm 0.13\end{array}$ \\
\hline 3 & E. africana & 9 & $\begin{array}{l}44.44 \\
\pm 1.39\end{array}$ & $\begin{array}{c}117.17 \pm 8 \\
.29\end{array}$ & $\begin{array}{l}13.14 \\
\pm 2.20\end{array}$ & $\begin{array}{c}8.53 \\
\pm 0.46\end{array}$ & $\begin{array}{c}0.50 \\
\pm 0.13\end{array}$ & $\begin{array}{c}13.31 \pm \\
1.30\end{array}$ & $\begin{array}{c}14.54 \pm \\
1.32\end{array}$ & $\begin{array}{l}38.31 \\
\pm 3.72\end{array}$ & $\begin{array}{c}0.99 \\
\pm 0.07\end{array}$ \\
\hline 4 & Weedy types & 2 & $\begin{array}{l}53.00 \\
\pm 3.00\end{array}$ & $\begin{array}{c}160.22 \pm 2 \\
0.04\end{array}$ & $\begin{array}{l}12.40 \\
\pm 4.60\end{array}$ & $\begin{array}{c}9.40 \\
\pm 0.00\end{array}$ & $\begin{array}{c}0.53 \\
\pm 0.05\end{array}$ & $\begin{array}{c}18.60 \pm \\
1.22\end{array}$ & $\begin{array}{c}19.76 \pm \\
1.42\end{array}$ & $\begin{array}{c}33.93 \\
\pm 13.35\end{array}$ & $\begin{array}{c}1.19 \\
\pm 0.21\end{array}$ \\
\hline
\end{tabular}

( $\mathrm{N}=$ Number of genotypes)

Table.4 The contribution of nine quantitative morphological traits to the variation in PC1 and PC2

\begin{tabular}{|c|c|c|}
\hline Trait & PC1 $(38.33 \%) *$ & PC2 $(23.27 \%)^{*}$ \\
\hline A (Days to $50 \%$ flowering) & 0.30 & -0.07 \\
\hline B (Plant height - cm) & 0.23 & 0.52 \\
\hline C (Productive tillers / plant) & 0.32 & -0.45 \\
\hline D (Finger numbers/ear head) & -0.03 & 0.22 \\
\hline E (Finger width - cm) & -0.41 & -0.04 \\
\hline F (Finger length - cm) & 0.47 & 0.27 \\
\hline G (Ear head length - cm) & 0.46 & 0.29 \\
\hline H (Flag leaf length - cm) & -0.31 & 0.43 \\
\hline I (Flag leaf width - cm) & -0.25 & 0.35 \\
\hline
\end{tabular}

(*Values in parenthesis are Per cent variance explained by PC1 and PC2)

Fig.1 The dendrogram showing relatedness among 28 genotypes using 23 morphological traits

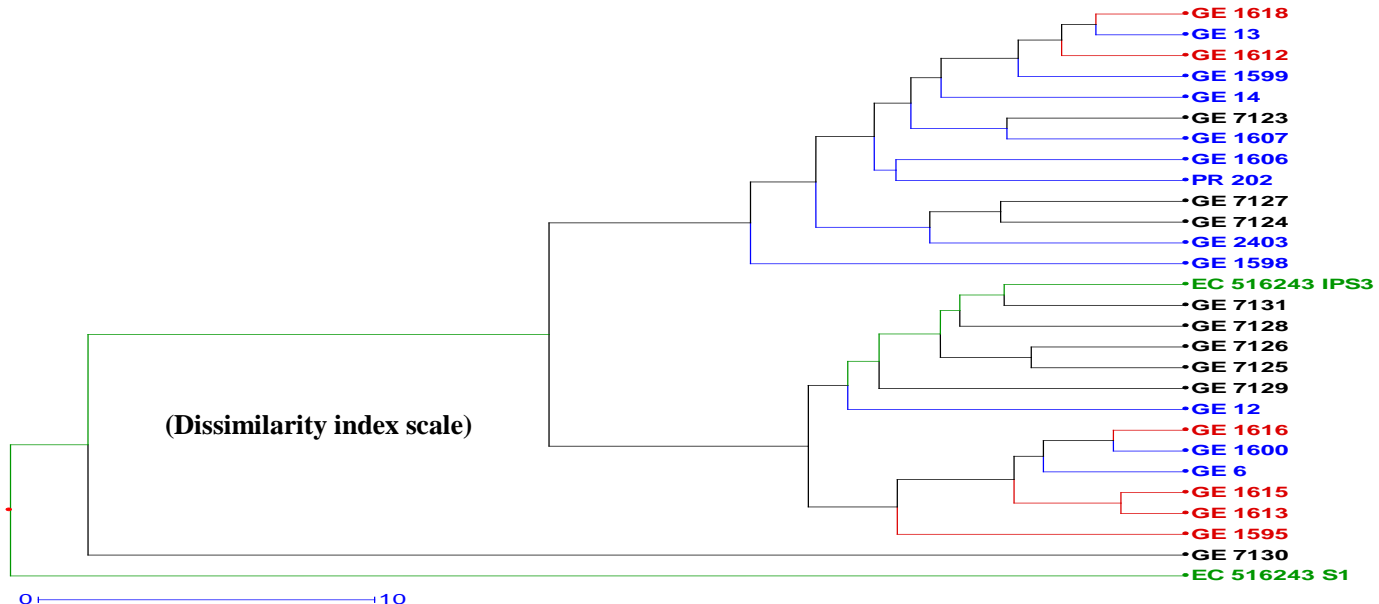

(Blue- Cultivated genotypes from India, Red- Cultivated genotypes from Africa, Black- E. africana, Green- Weedy types of E. coracana) 
Fig.2 The dendrogram showing relatedness among 28 genotypes using 14 qualitative morphological traits

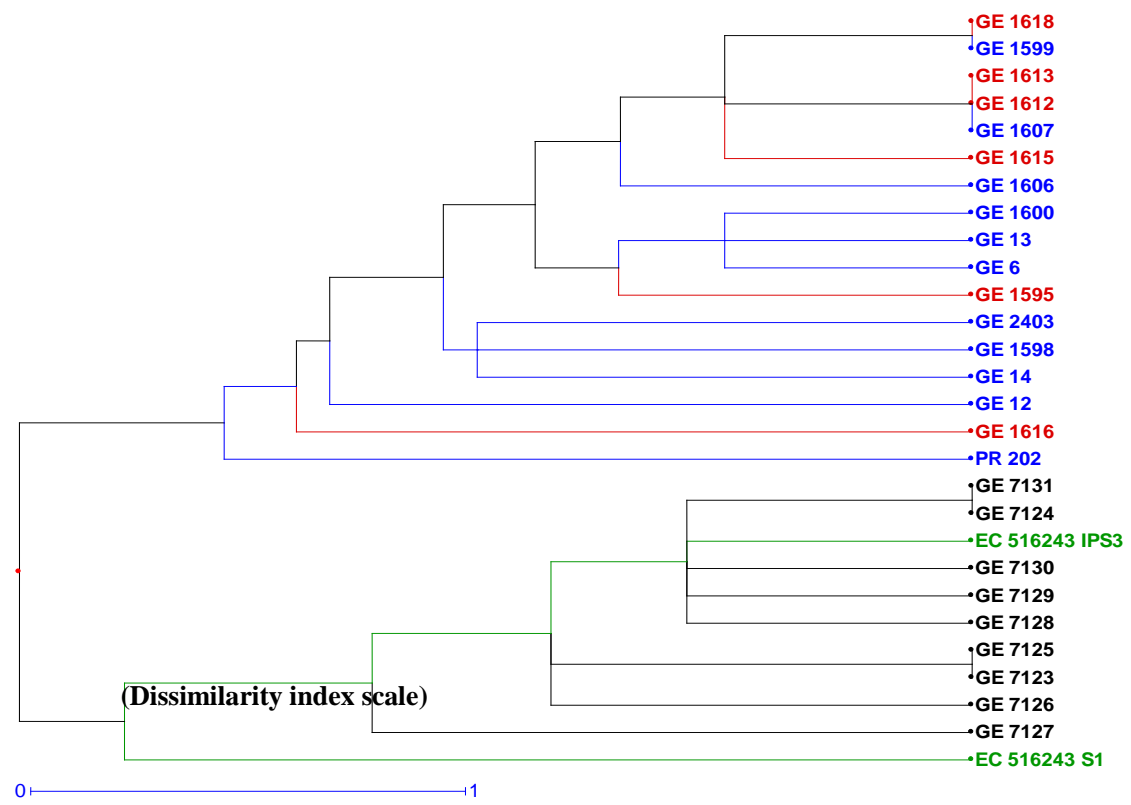

(Blue- Cultivated genotypes from India, Red- Cultivated genotypes from Africa, Black- E. africana, Green- Weedy types of E. coracana)

Fig.3 The principal component analysis scatter bi-plot showing the distribution of 28 genotypes of using nine quantitative morphological traits

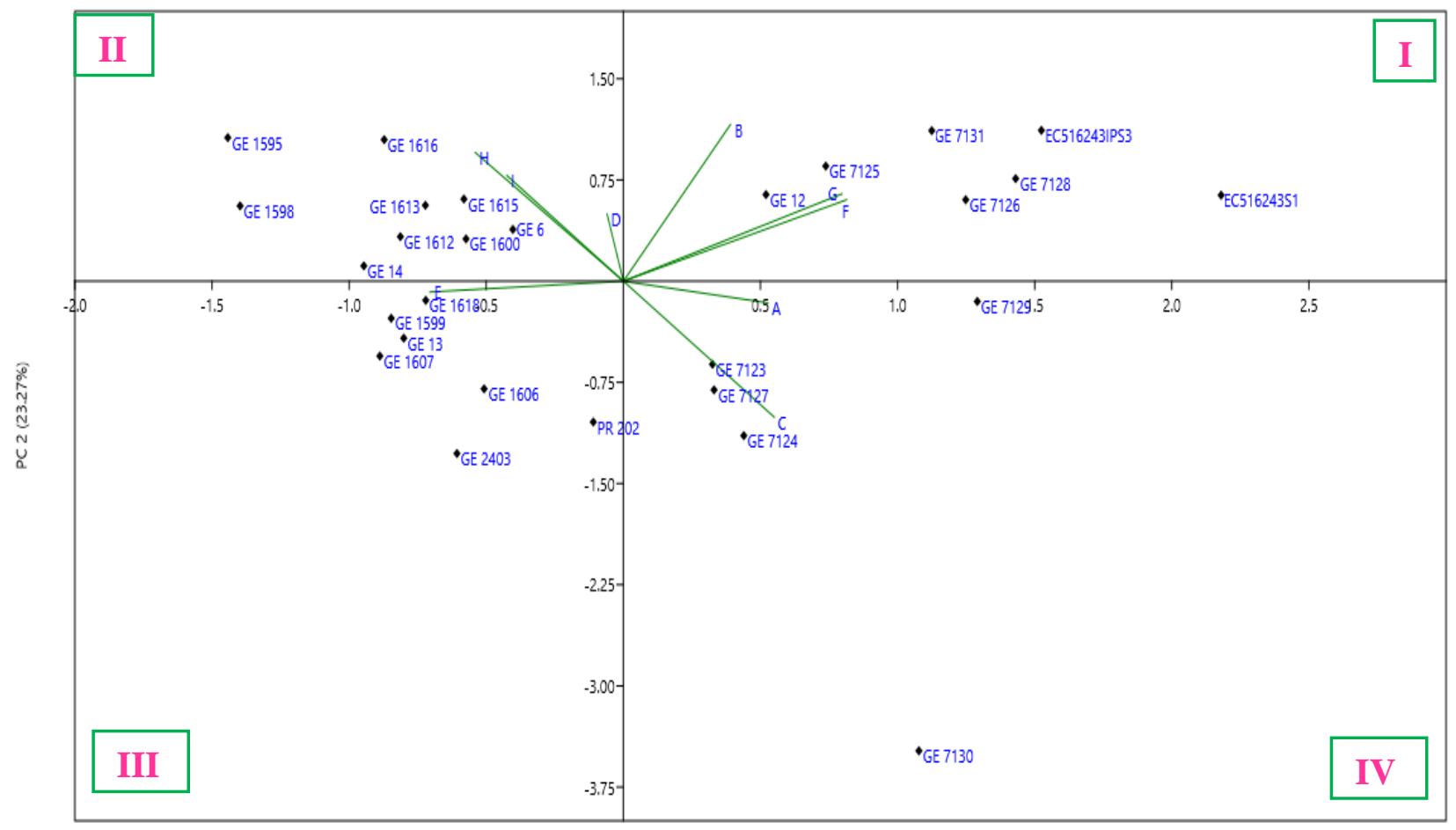

PC 1 (38.33\%) 
Fig.4 The dendrogram showing similarity relationship among 14 genotypes using SSR markers

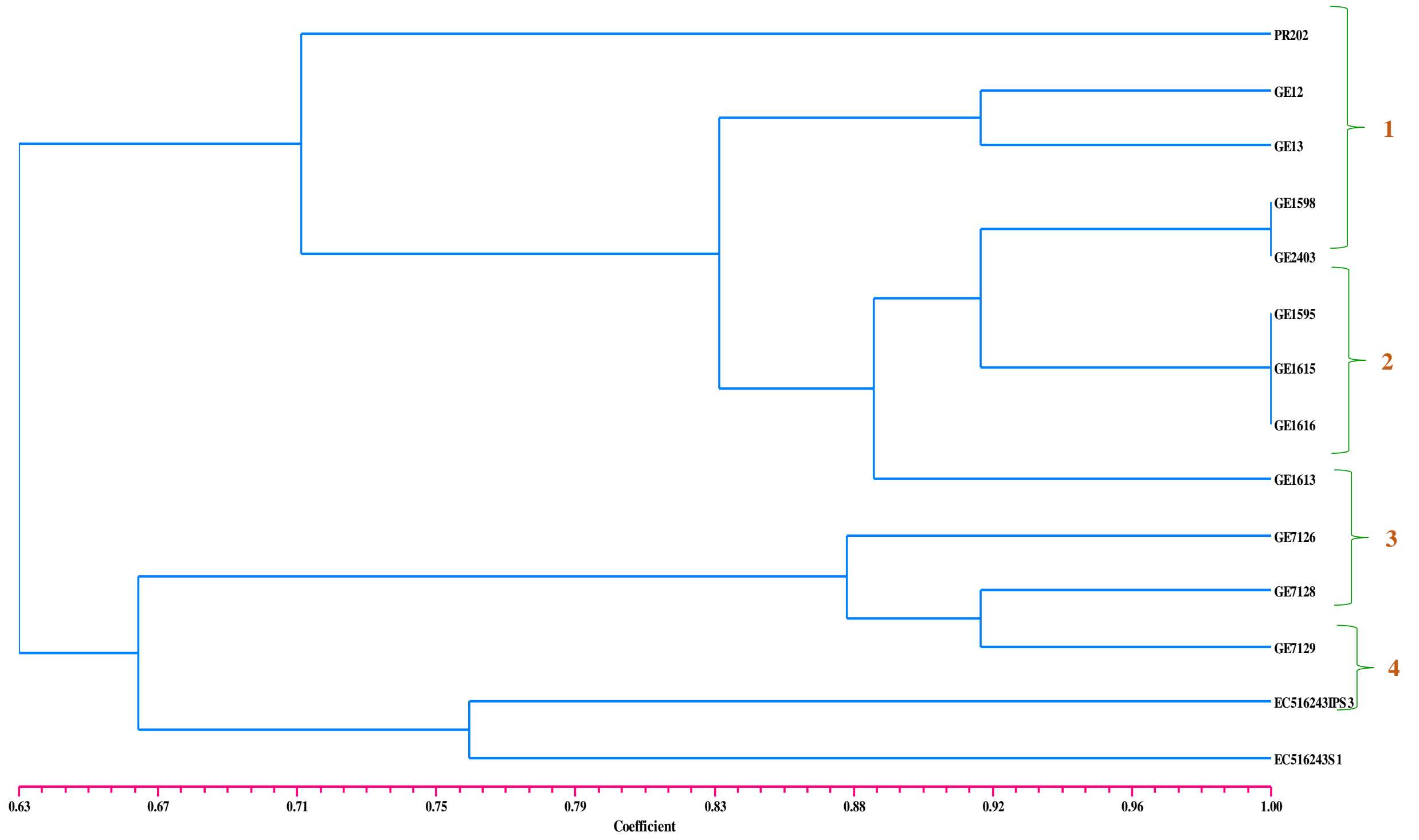

(1- Cultivated genotypes from India, 2- Cultivated genotypes from Africa, 3- E. africana, 4- Weedy types) 
Fig.5 The principal coordinate analysis scatter plot showing the distribution of 14 genotypes using SSR markers

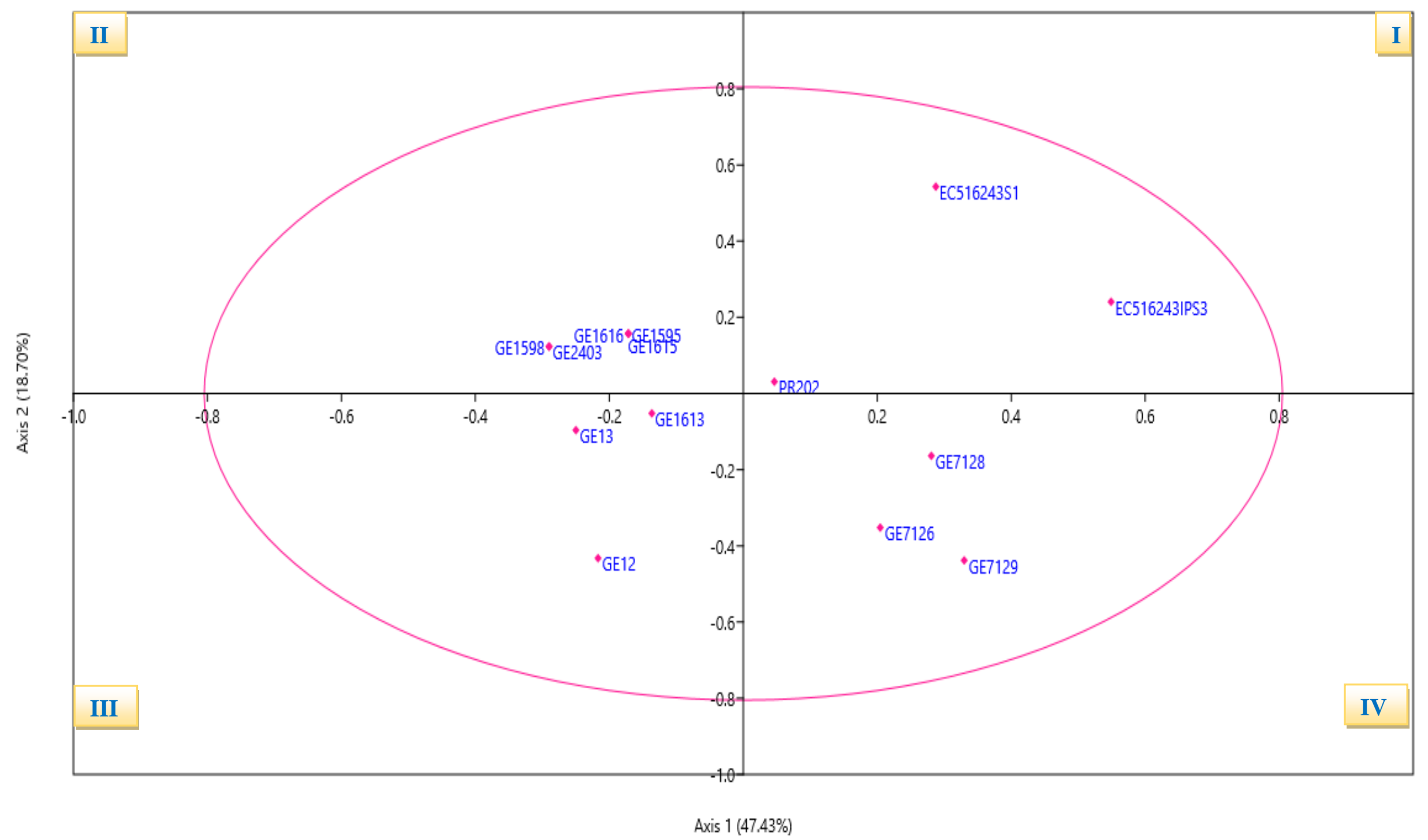


The polymorphic information content (PIC) for SSR loci ranged from 0.00 to 0.37 , and the average PIC value was 0.13 . The cultivated genotypes expressed lower mean genetic diversity index (0.08) and mean PIC value (0.06) as compared to the genetic diversity index (0.13) and PIC value (0.10) of wild species and weedy types. The lower genetic diversity in in cultivated finger millet genotypes has been reported by many workers earlier (Dida et al., 2008; Arya et al., 2013; Nethra et al., 2014; Dagnachew et al., 2014). The narrow genetic base among the cultivated genotypes could be due to domestication bottlenecks.

The cluster analysis based on UPGMA analysis divided the genotypes into two major clusters I and II (Fig. 4). All the nine cultivated genotypes (Eleusine coracana) were clustered in major cluster I while the genotypes of E. africana and weedy types were grouped in cluster II. Furthermore, genotypes of $E$. africana were clustered separately from weedy types in different subclusters of cluster II. But genotypes of cultivated types from India and Africa didn't segregate according to origin of collection. Such a mixed clustering of Indian and African cultivated genotypes has been previously observed by Arya et al., (2013) and Ramakrishnan et al., (2016).

The Principal Coordinate Analysis (PCoA) scatter plot demonstrated a comparable distribution of genotypesin different quadrants similar to the grouping revealed by cluster analysis. The contribution from first axis was $47.43 \%$ while the second axis contributed $18.70 \%$ to the total variation. The three cultivated genotypes of Africa viz. GE 1595, GE 1616 and GE 1615 were clumped at a point in the second quadrant.Both the weedy E. coracana types were grouped together in quadrant I along with cultivated genotype PR 202. (Fig. 5).
In summary, it can be observed that considerably lower genetic diversity was found in the cultivated types than in the wild samples. The cluster analysis and multivariate analysis conducted with morphological data was found to be consistent with that of analysis made with SSR marker data in separating the cultivated genotypes from wild and weedy types. The tetraploid weedy types having superior yield attributing traits could be an important source to enhance the diversity among the cultivated types through hybridization. Attempts are being made to cross the weedy species with cultivated genotypes to introgress the desired traits.

\section{Acknowledgement}

The first author (Chitra Joshi) is highly thankful to DBT-HRD for providing the scholarship and the contingency grant. We further express special thanks to the Project Coordinator, All India Coordinated Research Project on Small Millets (AICRPSM), GKVK, Bangalore for supplying the seeds of finger millet genotypes used in this study.

\section{References}

Arya, L., Verma, M., Gupta, V. K. and Seetharam, A. 2013. Use of genomic and genic SSR markers for assessing genetic diversity and population structure in Indian and African finger millet (Eleusine coracana (L.) Gaertn.) Germplasm. Plant Syst. Evol.299: 13951401.

Babu, B. K., Agrawal, P. K., Pandey, D., Jaiswal, J. P. and Kumar, A. 2014a. Association mapping of agromorphological characters among the global collection of finger millet genotypes using genomic SSR markers. Mol. Biol. Rep. 41: 5287-5297.

Babu, B. K., Agrawal, P. K., Pandey, D., Sood, S., Chandrashekara, C. and 
Kumar, A. 2014b. Molecular analysis of world collection of finger millet accessions for blast disease resistance using functional SSR markers. SABRAO J. Breed. Genet. 46: 202-216. Chennaveeraiah, M. S. and Hiremath, S. C. 1974. Genome analysis of Eleusine coracana (L.) Gaertn. Euphytica.23.

Dagnachew, L., DeVilliers, S., Sewalem, T., Dida, M., Masresha, F., Kimani, W. and Kassahun, T. 2014. Genetic diversity and eco-geographical distribution of Eleusine species collected from Ethiopia. Afr. Crop Sci. J. 22(1): 45-58.

DeWet, J. M. J. 1995. Finger millet. Evolution of Crop Plants. 137140.

Dida, M. M., Wanyera, N., Dunn, M. H., Bennetzen, J. L. and Devos, K. M. 2008. Population structure and diversity in finger millet. Tropical Plant Biol.1: 131-141.

Doyle, J. J. and Doyle, J. L. 1987. Rapid DNA isolation procedure for small quantities of fresh leaf tissue. Phytochem Bull.19: 11-15.

Goron, T. L. and Raizada, M. 2015. Genetic diversity and genomic resources available for the small millet crops to accelerate a New Green Revolution. Front. Plant. Sci. 6: 157.

Hammer, Ø., Harper, D.A. T. and Ryan, P.D. 2001. Paleontological statistics software: Package for education and data analysis. Palaeontol. Electron.4.

Harlan, J. R. 1971. Agricultural origins: centres and non-centres. Science. 174(4008): 468-474.

Katzman, L. S., Taylor, A. G. andLanghans, R. W. 2001. Seed enhancements to improve spinach germination. Hort. Science. 36(5): 979-981.

Kumar, D., Tyagi, V., Ramesh, B. and Pal, S. 2010. Genetic diversity in finger millet (Eleusine coracana L.). Crop Improvement. 37(1): 25-28.
Liu, K. and Muse, S. V. 2005. Power Marker: an integrated analysis environment for genetic marker analysis. Bioinformatics.21: 2128-2129.

Mahanthesha, M., Sujatha, M., Pandravada, S. R. and Meena, A. K. 2017. Study of Genetic Divergence in Finger Millet (Eleusine coracana L. Gaertn.) Germplasm. Int. J. Pure App. Biosci. 5(3): 373-377.

Mariam, A. L., Zakri, A. H., Mahani, M. C. and Normah, M. N. 1996. Interspecific hybridization of cultivated rice, Oryzasativa L. with the wild rice, $O$. minuta Presl. Theor. Appl. Genet. 93(5): 664-671.

Michaelraj, P. S., Shanmugam, A. 2013. A study on milletsbased cultivation and consumption in India. International Journal of Marketing, Financial Services and Management Research. 2(4):49-58.

Naik, B. J., Gowda, B. S. andSeetharam, A. 1993. Pattern of variability in relation to domestication of finger millet in Africa and India. Advances in small millets.Oxford and IBH Publishing Co. Pvt. Ltd., New Delhi. 347-364.

Nethra, N., Gowda, R., Rajendra P. S., Hittalmani, S., Ramanjini Gowda, P. H. and Chennakeshava, B. C. 2014. Utilization of SSRs to estimate the degree of genetic relationships in finger millet (Eleusine coracana L. Gaertn.) genotypes and subspecies. SABRAO J. Breed. Genet. 46(1): 136-149.

Perrier, X. and Jacquemoud-Collet, J. P. 2006. DARwin software, http://darwin.cirad.fr/darwin.

Ramakrishnan, M., Antony Ceasar, S., Duraipandiyan, V., Al- dhabi, N. A. and Ignacimuthu, S. 2016. Assessment of genetic diversity, population structure and relationships in Indian and non- Indian genotypes of finger millet [Eleusine coracana (L.) Gaertn] using 
genomic SSR markers. Springer Plus. 5: 120.

Reddy, V. G., Upadhyaya, H. D., Gowda, C. L. L. and Singh, S. 2009. Characterization of eastern African finger millet germplasm for qualitative and quantitative characters at ICRISAT. Journal of SAT Agricultural Research. 7: 1-9.

Rohlf, F. J. 1998. NTSYSpc: Numerical Taxonomy System, ver. 2.20. Exeter Publishing Ltd., Setauket, NY.

Ulaganathan, V. and Nirmalakumari, A. 2015.
Finger millet germplasm characterization and evaluation using principal analysis. SABRAO J. Breed. Genet. 47(2): 79-88.

Upadhyaya, H. D., Gowda, C. L. L., Pundir, R. P. S., Reddy, V. G. and Subesingh. 2006. Development of core subset of finger millet germplasm using geographical origin and data on 14 quantitative traits. Genet. Resour. CropEv. 53(4): 679-685.

\section{How to cite this article:}

Chitra Joshi, Sunil Subramanya and Ravikumar, R.L. 2018. Evaluation of Morphological and Molecular Diversity among the Genotypes of Eleusine africana, Cultivated and Weedy Types of Finger Millet (Eleusine coracana L. Gaertn.). Int.J.Curr.Microbiol.App.Sci. 7(02): 18361848. doi: https://doi.org/10.20546/ijcmas.2018.702.221 